\title{
Princípios constitucionais da coação processual $\left({ }^{*}\right)$
}

\author{
Joaquim Canuto Mendes de Almeida
}

1. A' entrada desta preleção, que intitulámos "Princípios constitucionais da coação processual", parece-nos necessário declarar o que seja çação processual. E’ o que, desde logo, vamos fazer.

O desenvolvimento da atividade processual penal reclama, como garantia de satisfatória eficácia, a presença de determinadas pessoas (indiciados, testemunhas, peritos) e, não raro, a disponibilidade, para o juiz, de certas coisas.

0 interesse, que corresponde a tal exigência, é tutelado, segundo as leis, pelos institutos:

$1 .^{\circ}$ - da ordem de comparecimento, sob pena de revelia;

$2 .^{\circ}$ - da condução debaixo de vara;

$3 .^{\circ}$ - da captura e da custódia, que são, respectivamente, os atos de efetuar a prisão e de conservá-la;

$4 .^{\circ}$ - da fiança, meio de coação moral, que, entretanto, faculta aos indiciados eximirem-se á coação física da prisão;

$5 .^{\circ}$ - e, finalmente, quanto ás coisas, das ordens de exhibição (sob pena de busca pessoal ou domiciliar) ou de apreensão.

(*) Aula inaugural do ano letivo de 1940. 
A coação processual, como se vê, distingue-se em coação pessoal e coação real: uma se exerce sobre pessoas e outra sobre coisas.

Interessa-nos, nesta lição, bordar comentários exclusivamente acerca da coação pessoal, que, no dizer de Manzini, "consiste numa limitação mais ou menos intensa da liberdade individual de uma pessoa para satisfação do escopo processual penal"

Nosso estudo - para sermos ainda mais preciso - recairá, restritamente, sobre a coação processual que se exerce sobre os réus, por meio da prisão preventiva "em sentido lato" e da fiança.

2. A prisão preventiva “em sentido lato", é bem de ver, não se confunde, por sua natureza e finalidade, com a prisão penal.

A. A finalidade da pena é, segundo as diversas escolas penais, respectivamente: expiação, escarmento, castigo exemplar, intimidação, segregação da vida social, meio de readaptação, de cura, de educação.

B. A prisão processual tem outro objetivo: destina-se a segurar o réu para que não fuja.

3. A lei penal, na verdade, não se realizaria se, pela fuga, pudessem os réus obstar-lhe a aplicação. A execução penal seria frustrada. Para que tal não ocorra, trata-se, então, (desde que pese sobre alguem uma acusação criminal) de evitar sua fuga. O melhor meio de fazê-lo é segurar o acusado, isto é, prendê-lo e conservá-lo na prisão, até que o poder judiciário decida da procedência ou improcedência da imputação.

4. A prisão, entretanto, garante, contra a fuga, não só o cumprimento eventual da pena, mas tambem acautela a fluência do movimento processual. É, em suma, como ensinou João Mendes Junior, uma das cauções da instância. 
Convém observar, todavia, que a instância só deve ser caucionada por meio da prisão:

a) quando a conciência jurídica do legislador entende que o processo não se deve mover sem que o indiciado efetivamente participe da sua atividade; ou,

b) ao menos, que o processo não se deve mover sem que esteja o indiciado presente a atos da instrução.

No primeiro caso, o legislador tutela, por meio da prisão, o direito á contrariedade; no segundo caso, o interesse da verificação da verdade real.

5. Tratemos do primeiro caso, isto é, da prisão preventiva, no sentido lato, considerada como expressão do princípio do contraditório.

Como a revelia, é um meio de garantir a efetividade da defesa. Contudo, difere da revelia em que esta coage moralmente o réu a participar da atividade processual; ao passo que a prisão coage fisicamente.

A revelia depende da disciplina da citação, da notificação, da intimação; e, desde que ao indiciado apareça como um mal, lhe impõe, pelo terror de sofrê-lo ou de experimentar-lhe nefastas consequências, efetiva participação na atividade processual: "la parte é stimolata a contraddire -... ensina CARNelutTI - in quanto la sua inatività in giudizio la collochi in una situazione sfavorevole rispetto alla decizione della lite"

São reduzidas, porém, ao mínimo, no processo penal, as desvantagens da revelia: não ha pena de confesso, nomeia-se um defensor ao revel e o juiz é inquisitivo; cumpre ela, entretanto, satisfatóriamente sua função nos casos de infrações leves, porque o réu sempre ou quasi sempre teme a própria ausência.

Nos casos mais graves, porém, só a prisão ou, ao menos, a fiança garante a contrariedade, para o réu não temer menos a própria ausência do que a pena. O réu é seguro, por meio delas, para participar da atividade processual, afim de que não tolha, pela ausência ou pela fuga, o curso da causa. 
6. Tratámos da prisão processual e da fiança como meios de garantir, quer a execução da pena, quer a contrariedade. Examinêmo-las, agora, como meios de instrução.

o ladrão que testemunhas viram, mas não conheciam, o assassino que, desferido o golpe, fugiu perseguido por populares, devem, muita vez, ser reconhecidos pelos sinais fisionômicos, o que só é possivel (salvo o caso de reconhecimento fotográfico, que é imperfeito) pela confrontação com as testemunhas. Seu interrogatório informativo, a colheita de sinais gráficos, exames em seus ferimentos, etc., tambem exigem sua presença, para a perfeição da prova. Para que o acusado, então, não se furte á confrontação, ao reconhecimento, aos exames, é seguro pela prisão processual.

7. Pois bem, a prisão processual - segurança do réu para que não fuja; medida acauteladora da execução da pena e da fluência da causa, onde o legislador acha indispensavel o contraditório efetivo - é disciplinada pelo art. 122 n. $^{\circ} 11$ da Constituição Nacional:

“à exceção do flagrante delito - diz o texto - a prisão não poderá efetuar-se senão depois da pronúncia do indiciado, salvo nos casos determinados em lei e mediante ordem escrita da autoridade competente. Ninguem poderá ser conservado em prisão sem culpa formada, senão pela autoridade competente, em virtude da lei e na fórma por ela regulada"

Traduzem-se esses preceitos por esta fórma:

1) a prisão depende de pronúncia. (regra)

2) flagrante delito.

3) casos determinados em lei (e mediante ordem escrita da autoridade competente);

4) a conservação em prisão depende, nos três casos, de formação da culpa, por autoridade competente, em virtude de lei e na fórma por ela regulada. 
Eis os princípios constitucionais da coação processual. Examinêmo-los detidamente para deles extrairmos todos os seus corolários. $\mathrm{O}$ exame ha de revelar pela determinação da natureza jurídica dos institutos: a) que a pronúncia não é causa, mas simples condição, da prisão processual $e$ da fianga; b) que, sendo condição, não o é senão acidentalmente, embora por fôrça de dispositivo constitucional.

8. A pronúncia, instituto antiquíssimo em nosso direito, era, segundo os mestres, "o decreto do juiz (proferido sobre a devassa ou sobre a querela dada por alguem) declarando o indigitado indiciado em crime, determinando o modo por que se devia livrar da acusação e mandando por o seu nome no ról dos culpados"

Era, mais resumidamente, a declaração judiciária do crime e do criminoso, para base da acusação.

O modo do livramento defluia da natureza do crime, definida pela pronúncia, e da letra das Ordenações; mas a pronúncia era ordinária, quando permitia que o réu se livrasse solto (quando reus solutos se purgat a crimine, dizia Mello Freire); e especial, quando determinava que o réu se livrasse prêso (pronúncia de reo capiendo) ou que, para não ser prêso, obtivesse carta de seguro (pronuncia de reo tanquam securo). "Na prática (ensinava JoÃo Mendes JúNIOR) só se denominava pronúncia á pronúncia especial”

A pronúncia era, em suma, a determinação judicial dos termos da acusação. Indireta e acidentalmente é que, determinada a natureza do delito, a pronúncia estatuia, ipso facto, o modo de livramento, mas por força das leis de coação processual.

A prática reservou, todavia, - repitamos - o nome de pronúncia exclusivamente para aquela de que decorria a prisão (ou a obrigação de fiança) do indigitado delinquente.

9. Ora, não prossigamos sem frizar que da prática essa restrição terminológica passou para as leis.

A Constituição Nacional de 1824, implicitamente adotou o conceito de pronúncia no seu sentido estrito, nos ns. 8,9 e 10 do art. 179 . 
Os princípios ali consignados, de que "ninguém poderá ser prêso sem culpa formada": de que "ainda com culpa formada, ninguém será conduzido á prisão ou nelas conservado, estando já prêso, se prestar fiança idônea"; de que em certas infrações leves, poderá "o réu livrar-se solto"; e de que "á exceção do flagrante delíto, a prisão não pode ser executada senão por ordem escríta da autoridade legítima" ligaram, decisivamente, os institutos da prisão e da fiança á formação da culpa e, por isso mesmo, á pronúncia, que é seu ponto final. Assim o entendeu o legislador pátrio durante a vigência de tais princípios constitucionais, que respeitou, tanto na elaboração do Código de Processo Criminal, da lei n. 261 de 3 de dezembro de 1841 e seu regulamento $n .^{\circ} 120$, quanto na da lei $n .^{\circ} 2.033$ e seu regulamento n. 4.824 de 1871.

Esses estatutos mantiveram-se fieis ao conceito constitucional: a formação da culpa e pronúncia foram, neles, reservadas aos processos dos crimes afiançáveis e inafiançáveis, e dispensadas quanto aos processos das infrações mais leves, das quais os acusados se livram soltos.

Mas, a despeito disso, a pronúncia, embora exigida como condição "sine qua non" apenas das acusações por crimes inafiançáveis e afiançáveis, não mudou de natureza. Continuou a ser, como sempre foi, um juizo de acusação. Ora, que é um juizo de acusação?

10. Juizo de acusação é uma operação jurisdicional diversa do juizo da causa. Consiste o juizo da causa em dizer de um ato que é passivel de pena; o juizo de acusaçẫo se destina a decidir que ha base probatória para nela assentar-se uma acusação.

o juizo da causa declara, em concreto, o direito de punir; o juizo de acusação exprime, em concreto, o direito de acusar.

O juizo de acusação funda-se numa instrução preliminar (a pronúncia se funda na formação da culpa). É, segundo Faustin Hélie. "instituição indispensável á justiça penal" 
Seu beneficio é "proteger o inculpado" Dá á defesa a faculdade de dissipar as suspeitas, de combater os indícios, de explicar os fatos e de destruir a prevenção no nascedouro; propicia-lhe meios de desvendar prontamente a mentira e de evitar a escandalosa publicidade do processo criminal injusto. Todas as pesquisas, investigações, testemunhos e diligências são submetidos a sério exame para, de antemão, se regeitar tudo o que não gera graves presunções, quantas bastem para sério sustentáculo de uma ação penal. Previne-se, assim, a justiça contra imputações temerárias, caluniosas ou infundadas.

A pronúncia equivale, pois, na sua finalidade, aos despachos de "mise en accusation", do direito francez; de "invio a giudizio", do direito italiano, que encerram a instrução prévia; e ao "true bill", do direito inglês.

11. A pronúncia é, em suma, um juizo de acusação, uma licença judicial para se acusar alguem, instituida sempre que o legislador entende de boa cautela proteger a inocência contra os processos criminais temerários. Exigindoa, porém, o direito pátrio tão só para as acusações por crimes afiançáveis e inafiançáveis, faz dela, embora de modo indireto e acidental, um meio de proteção da inocência estritamente contra a coação processual que a prisão preventiva (lato sensu) e a fiança representam.

Notem: é meio "contra" e não "de" coação processual.

Da Contituição imperial essa subordinação (dos dois institutos coativos á condição de pronúncia) passou para as duas Constituições dos estados autônomos do Brasil (de 1891 e de 1934) e, finalmente, para a Constituição Nacionai, art. 122 n..$^{\circ}$ 11: "a prisão não poderá efetuar-se senão depois de pronúncia do indiciado" (á exceção do flagrante delito e dos casos determinados em lei). A fiança, sendo meio de se eximir o indiciado de prisão processual e, por isso, supondo a prisão processual, é subordinada igualmente á pronúncia. 
12. A regra Constitucional sofre, como vimos, duas exceções, em virtude das quais se admitem a prisão e a fiança mesmo sem prévia pronúncia: a do flagrante delito e a dos "casos determinados em lei e mediante ordem escríta da autoridade competente", casos esses que são os da denominada prisão preventiva (stricto sensu).

Essas exceções, entretanto, é bem de vêr, só se referem ao ato de captura, mas não á conservação do indiciado na prisão. (A ambiguidade do termo "prisão" na nossa técnica processual dificulta a distinção entre a captura e a custódia do prêso, pois a ambas se aplica.)

O legislador constitucional de 1937 quiz, porém, ser claro (e nisso excedeu em liberalismo os constituintes de 1934) e usou de expressões que tornam nítida a distinção, restaurando-a (pois figurava nas Constituições de 1824 e 1891) :

ao passo que podem os indiciados ser capturados em consequência quer de pronúncia, quer de flagrante delito, quer de ordem legítima de prisão preventiva, "ninguém póde ser conservado em prisão - reza a segunda parte do princípio constitucional - sem culpa formada, senão pela autoridade competente, em virtude de lei e na fórma por ela regulada".

13. Não ha dúvida, pois, de que, assim sendo, nossas futuras leis de processo criminal são obrigadas, por fôrça da Constituição Nacional, a estatuir, para as infrações inafiançáveis e afiançáveis, que os respectivos processos judiciais contenham, inicialmente, formação da culpa.

Deverá o código de processo criminal do Brasil disciplinar a coação processual de modo que ninguém possa ser prêso ou obrigado a prestar fiança sem que a sua acusação dependa de pronúncia.

Quer a captura tenha sido em flagrante ou em virtude de decretação preventiva, quer decorra de formação de culpa, a disciplina da coação processual ha de, na nova lei, subordiná-la á pronúncia, porque a conservação do indicia- 
do na prisão é, textual e expressamente, subordinada pela Constituição á formação da culpa.

\section{CRíTICA}

14. Inconstitucionais são as leis que, provindo de poderes legislativos estaduais (sem autoridade para regulamentar a matéria da prisão e da fiança), suprimiram a pronúncia e a formação da culpa dos processos de crimes inafiançáveis e afiançáveis.

Dispensamo-nos, aqui, de citar tais leis. Entretanto, existem e os tribunais não lhes negam aplicação.

Á vista dessa jurisprudência, delitos inafiançáveis e afiançáveis tornam-se, na prática, extra-afiançáveis, infrações de que o réu de livra solto. Tal se dá, como se vê, pelo simples fato da supressão.

Exemplo curioso do papel da pronúncia como condição da coação processual é o dos crimes contra a economia popular. São estes, como se sabe, nominalmente inafiançáveis; mas o são apenas nominalmente, por mera declaração legislativa, que, na prática, se torna letra morta. Por dispensarem pronúncia os processos de competência do Tribunal de Segurança Nacional, o resultado é não haver oportunidade legal de ser determinada a prisão do acusado, antes da sentença. Este, então, defende-se sôlto. Seu crime é, de fato, infração de que o réu se livra sôlto.

15. Ha, ainda, entre nós, a-pesar-disso, muitos inimigos do instituto da pronúncia. Raros, porém, são os que the conhecem a natureza e a função essencial: prevenir a justiça contra as acusações temerárias.

Vêm-lhe, alguns mais, tão só a função indireta e acidental de condição da coação processual. Poucos, assim, podem opinar com conhecimento de causa.

A pronúncia, entretanto, é utilissima e, não raro, indispensável á justiça penal. Essa é nossa opinião, corroborada 
pelos códigos de processo mais modernos, de nações cultas, que a manteem, embora sob diversos nomes.

Os abolicionistas, contudo, sob certos aspectos, merecem atenção. A pronúncia, realmente, da maneira como funciona entre nós, é um entrave ao progresso. Não deve ser suprimida, porém restaurada na pureza de sua essência. E' preciso que seja desligada de sua função acidental (de condição de prisão e de fiança), para que liberte esses institutos de coação processual. Embora a prisão ou a obrigação de fiança sejam em nosso direito, consequências da pronúncia, esta não tem por fim específico determiná-las, mas apenas permitir acusação. É a sujeição do réu a acusação que acarreta a coação, tanto quanto a determinaria se pudesse aquela ser intentada independentemente de pronúncia e de formação de culpa: a impronúncia é, na prática, um meio de evitar a coação, mas a pronúncia não é um meio de determiná-la.

O exemplo do direito francez é expressivo: a prisão preventiva independe da "mise en accusation"

Na Itália, a custódia preventiva, tanto a obrigatória como a facultativa, independe tambem do despacho do "invio a giudizio" Ocorre mesmo nos casos do giudizio direttissimo, em que o processo se caracteriza pela falta de instrução preliminar e pela dispensa do despacho do "invío a giudizio" A custódia facultativa continua facultativa mesmo após a instrução preliminar, embóra seja regra que tanto para ela como para decretação da custódia obrigatória, devam subsistir suficientes indícios de "colpevolezza contro l'imputato", segundo o art. 252 do código de processo criminal de 1932 . E' claro que "il giudice con la sentenza che rinvia a giudizio ordina la cattura dell'imputato se questo non è già detenuto per il reato per cui si procede, quando si tratta di delitto per il quale la legge impone il mandato di cattura" (art. 375), porque para emitir essa sentença, nos termos do art. 374, deve reconhecer "che vi sono sufficienti prove a carico dell'imputato per rinviarlo a giu- 
dizio" e, ipso facto, que existem indicios obrigatórios da prisão.

16. Concluamos.

- A coação processual representa uma limitação da liberdade dos indivíduos para garantia de eficácia da atividade processual penal. Disciplina-as a Constituição; e leis ordinárias não podem contravir os princípios fundamentais da disciplina da coação processual.

- Entre tais princípios, um deles, tradicional em nosso direito, é muita vez esquecido pelos legisladores, locais ou não: o princípio de que ninguem (prêso ou em flagrante, ou por pronúncia ou preventivamente - pouco importa) pode ser conservado na prisão senão em consequência de formação da culpa. É esse esquecimento que os faz suprimirem a pronúncia em processos de crimes afiançáveis e de crimes inafiançáveis.

- Esse êrro, porém, tem, sob certo aspecto, uma virtude: mostra a inconveniência de o legislador da Constituição haver mantido ligados os institutos da prisão e da pronúncia. As funções são distintas. Por isso mesmo, não deviam ser entrelaçadas de uma maneira tão íntima. Dessa junção decorrem manifestos entraves ao progresso do nosso direito judiciário penal.

- À vista de tudo, os princípios constitucionais deveriam ser, não os consignados no art. 122 n..$^{\circ} 11$, mas os seguintes :

1) a exceção do flagrante delito ninguém poderá ser prêso ou conservado na prisão, nem obrigado a prestar fiança senão pela autoridade competente, em virtude de lei e na fórma por ela regulada;

2) ninguem poderá ser acusado sem culpa formada, salvo as exceções expressas em lei.

Esperamos que os doutos juristas, autores e revisores do prometido código do processo penal do Brasil, não desprezem essas observações, calcadas nos princípios expostos pelos grandes processualistas pátrios. 